\title{
OPTIMALISASI PENERAPAN PENDIDIKAN KARAKTER \\ PADA “KURIKULUM 2013” MENGGUNAKAN STRATEGI 3M DI SEKOLAH DASAR
}

\author{
1) Nur Asyiah¹ 2) Liyana Sunanto \\ ${ }^{1}$ FKIP Universitas Muhammadiyah Cirebon \\ Jl. Tuparev No. 70 Cirebon \\ Email: nurasyahm@gmail.com
}

\begin{abstract}
The purpose of this study is to obtain the learning device (syllabus, lesson plans, and student worksheet) integrated character education using 3M strategy (Knowing Moral, Moral Feeling, and Moral Action) on the curriculum in 2013, and look at the effectiveness of the learning device for shaping the character of the participants learners. The study design used was a quasi-experimental control grouph pre test-post test. This research was conducted in SDN 3 Klangenan and SDN 1 Sumber to fourth grade students. The effectiveness of the learning device is made to be seen from the results of student learning, character assessment, student response to learning. Based on these data we can conclude the application of learning curriculum 3M 2013 using effective strategies to improve students' character. Keywords: character education, curriculum 2013, 3M strategy.
\end{abstract}

Tujuan dari penelitian ini adalah untuk mendapatkan perangkat pembelajaran (silabus, RPP, dan lembar kerja siswa) untuk pendidikan karakter dengan menggunakan strategi 3M (Knowing Moral, Moral Feeling, and Moral Action) pada kurikulum tahun 2013, dan melihat efektivitas perangkat pembelajaran untuk membentuk karakter peserta didik. Desain penelitian yang digunakan adalah kuasi-eksperimental grup kontrol pre test-post test. Penelitian ini dilakukan di SDN 3 dan SDN 1 klangenan Sumber untuk siswa kelas IV. Efektivitas perangkat pembelajaran yang dibuat dilihat dari hasil belajar siswa, penilaian karakter, dan respon siswa untuk belajar. Berdasarkan hasil penelitian dapat disimpulkan bahwa penerapan pembelajaran kurikulum 2013 dengan menggunakan strategi 3M efektif untuk meningkatkan karakter siswa.

Kata kunci: pendidikan karakter, kurikulum 2013, strategi 3M.

PENDAHULUAN Pendidikan karakter menjadi isu utama dalam kurikulum 2013. Salah satu alasan perubahan kurikulum KTSP menjadi kurikulum 2013 adalah kualitas moral masyarakat yang semakin menurun. Isu tentang pendidikan karakter sudah lama terdengar, bahkan sebelum diterapkanya kurikulum 2013. Pada akhirnya saat ini pendidikan karakter merupakan program pendidikan nasional, harus diimplementasikan ke dalam lembaga pendidikan formal di seluruh jenjang pendidikan. Penerapan pendidikan karakter ini sebagai salah satu cara tercapainya tujuan pendidikan nasional yaitu menjadikan peserta didik menjadi manusia yang beriman dan bertakwa kepada tuhan yang maha esa, berakhlak mulia, sehat, berilmu, cakap kratif mandiri dan menjadi warga negara yang demokratis serta bertanggung jawab.

Pada saat ini yang diperlukan adalah kurikulum pendidikan yang berbasis karakter. Kurikulum yang bermuatan pendidikan karakter yang yang terintegrasi dalam materi ajar serta kegiatan pembelajaran yang diorientasikan kepada pembentukan karakter peserta didik. Perbaikan kurikulum merupakan bagian tak terpisahkan dari kurikulum itu sendiri, bahwa kurikulum yang berlaku harus dirubah secara 
terus menerus dengan memperhatikan kebutuhan yang berkembang dimasyarakat dan peserta didik. Untuk meminimalisir tingkat kriminal yang terjadi di masyarakat, serta mengembangkan sikap mulia pada peserta didik dirancangnya "kurikulum 2013".

Ketercapain Program pendidikan karakter yang terdapat dalam kurikulum 2013 tentunya dipengaruhi oleh pelaksanaan dalam proses pembelajaran di sekolah. Dalam pelaksanaannya tentu diperlukan strategi yang tepat agar hasil dari pendidikan karakter ini tidak hanya sebatas pada pengetahuan peserta didik tentang perilaku-perilaku yang baik.

Dalam penelitian ini, akan melihat keefektifan dari implementasi pendidikan karakter menggunakan strategi 3M (Moral Knowing, Moral Feel, Moral Action) pada "kurikulum 2013" untuk meningkatkan moral peserta didik sekolah dasar. Dengan melihat efektifitas penerapan strategi 3M pada implementasi pendidikan karakter di sekolah dasar ini dapat meningkatkan karakter peserta didik serta sebagai masukan para guru dalam mengimplementasikan pendidikan karakter pada pembelajaran.

Kurikulum 2013 menekankan penggunaan pendekatan ilmiah dalam proses pembelajarannya. Menurut kemendiknas (2013:220) dalam pembelajaran untuk menggali informasi melalui pengamatan, menanya, percobaan, mengolah data, dan networking.

Konsep implementasi kurikulum 2013 berkembang sejalan dengan perkembangan teori dan praktik. Proses pembelajaran harus menyentuh tiga ranah yaitu sikap, pengetahuan dan keterampilan. Hasil akhirnya adalah peningkatan keseimbangan antara kemampuan menjadi manusia yang baik, manusia yang memiliki kecakapan dan pengetahuan hidup yang layak.

Kata karakter berasal dari bahasa Yunani "charasein" yang berarti mengukir sehingga terbentuk sebuah pola. Memiliki akhlaq mulia tidak secara otomatis dimiliki setiap manusia begitu dilahirkan. Tetapi memerlukan proses panjang melalui pengasuhan dan pendidikan. terbentuknya karakter manusia ditentukan oleh dua faktor yaitu nature (faktor alami atau fitrah) dan nurture (sosialisasi dan pendidikan) (Megawangi, 2005).
Simon (1972) mengemukakan karakter adalah kumpulan tata nilai yang tertuju pada suatu sistem yang melandasi pemikiran, sikap dan perilaku yang ditampilkan. Sedangkan Beck (1981) memahami istilah karakter dengan dua pengertian. Pertama, ia menunjuk tentang bagaimana bertingkah laku. Apabila seseorang tidak jujur, kejam, atau rakus, tentulah orang tersebut memanifestasikan perilaku buruk. Sebaliknya, apabila seseorang berperilaku jujur, suka menolong, tentulah orang tersebut memanifestasikan karakter mulia. Kedua, istilah karakter erat kaitannya dengan personility. Seseorang baru disebut orang berkarakter apabila tingkah lakunya sesuai kaidah moral.

Sanusi (1998) menganggap bahwa karakter lebih dekat dengan akhlak, yaitu spontanitas manusia bersikap, atau melakukan perbuatan yang telah menyatu dalam diri manusia sehingga ketika muncul tidak dipikirkan lagi.

Menurut Lickona (2012) karakter dikonsepsikan memiliki tiga bidang yang saling terkait yakni Moral Knowing, Moral Feeling, dan Moral Action. Oleh karena itu, karakter yang baik memiliki tiga kompetensi, yakni mengetahui hal yang baik (knowing to good), ada keinginan terhadap hal yang baik (desiring the good), dan melakukan hal yang baik (Doing the good) sehingga pada gilirannya ia menjadi kebiasaan berfikir, kebiasaan hati dan kebiasaan bertindak. Menurut Lickona (2012) karakter dikonsepsikan memiliki tiga bidang yang saling terkait yakni Moral Knowing, Moral Feeling, dan Moral Action. Oleh karena itu, karakter yang baik memiliki tiga kompetensi, yakni mengetahui hal yang baik (knowing to good), ada keinginan terhadap hal yang baik (desiring the good), dan melakukan hal yang baik (Doing the good) sehingga pada gilirannya ia menjadi kebiasaan berfikir, kebiasaan hati dan kebiasaan bertindak.

Adapun langkah-langkah pembentukan karakter menurut Amri (2011:43) diantaranya yaitu:

1. Memasukan konsep karakter pada setiap pembelajaran dengan cara, (a) Menanamkan nilai kebaikan kepada anak (knowing the good). Menanamkan konsep diri pada anak setiap akan memasuki materi pelajaran; (b) Membuat cara yang membuat anak memiliki alasan atau keinginan untuk berbuat baik. (c) Memberikan beberapa contoh kepada anak 
mengenai karakter yang sedang di bangun; (d) Mengembangkan sikap mencintai perbuatan baik kepada anak; (e) Mengaplikasikan karakter dalam proses pembelajaran

2. Membuat slogan yang mampu menumbuhkan kebiasaan baik dalam segala tingkah laku siswa.

3. Pemantauan secara kontinyu, hal ini merupakan wujud dari pelaksanaan pembangunan karakter.

4. Penilaian orang tua memiliki peranan yang sangat besar dalam membangun karakter anak. Waktu anak lebih banyak dibandingkan waktu disekolah.

\section{METODE}

Desain penelitian yang digunakan adalah quasi eksperimen control grouph pre test-post test. Subjek yang digunakan dalam penelitian ini adalah peserta didik IV Sekolah Dasar di Kabupaten Cirebon terdapat dua kelas yang terdiri dari kelas eksperimen dan kelas kontrol. Pengumpulan data dilakukan melalui pretest, posttest, pengisian angket, observasi, dan wawancara.

Data yang diolah adalah data pretest dan postest yang dikumpulkan selama proses pembelajaran berlangsung. Data yang diperoleh kemudian dianalisis dengan langkah-langkah sebagai berikut: (1) Menilai tingkat ketercapaian karakter berdasarkan kriteria yang ditetapkan, (2) Menghitung rerata skor, (3) Uji normalitas, (4) Uji homogenitas, (5) Uji signifikansi, (6) Uji regresi, dan (6) Menghitung N-Gain.

\section{HASIL DAN PEMBAHASAN}

Karakteristik LKS yang di terapkan pada proses pembelajaran kurikulum 2013 yaitu pada sub tema "Pekerjaan Orang Tuaku" di kelas IV Sekolah Dasar. Adapun karakteristiknya yaitu dengan mengintegrasikan nilai-nilai karakter di dalamnya, selain itu juga dalam implementasinya menggunakan strategi 3M (Moral knowing, Moral Feeling, \& Moral Action) sebagai optimalisasi penerapan pendidikan karakter. Di bawah ini beberapa karakteristik LKS yang diterapkan yaitu:

Tabel 1. Karakteristik LKS Kurikulum 2013 Bermuatan Pendidikan Karakter

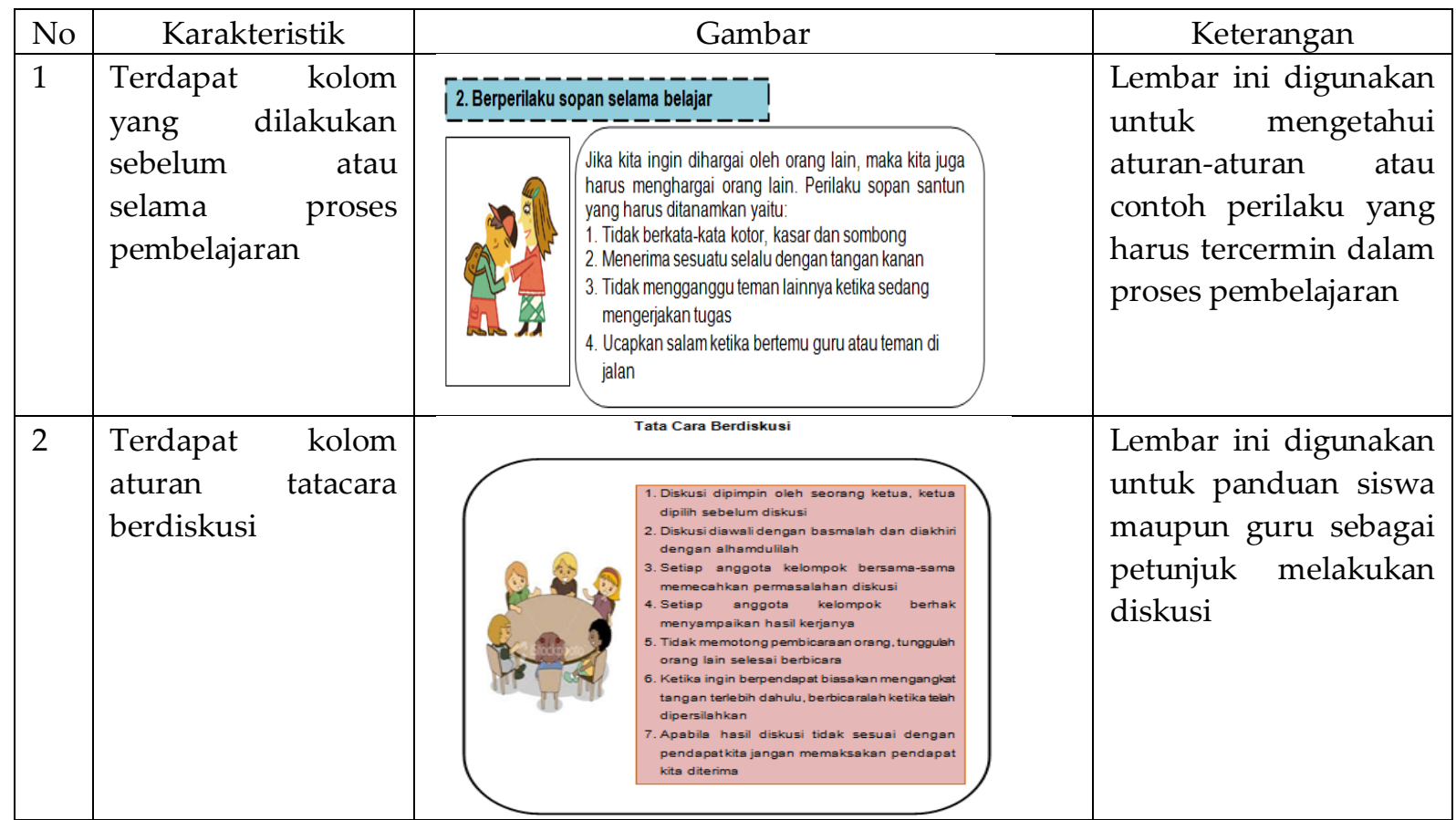




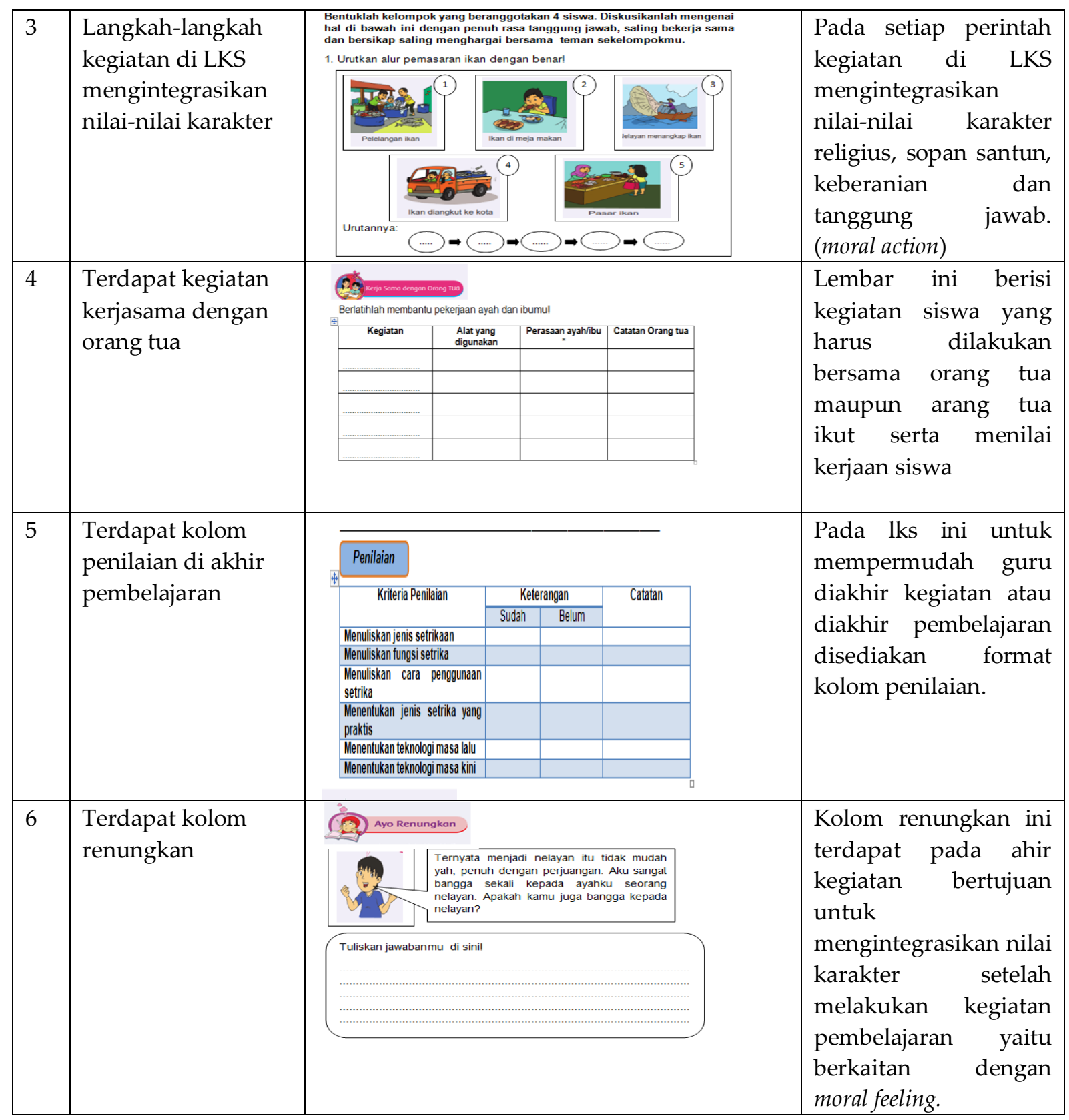

Data tentang keefektifan penerapan bahan ajar menggunakan strategi 3M terhadap peningkatan karakter dari hasil pengamatan pada saat pre test dan post test yang diberikan kepada peserta didik. Hasil pre test, post test dan \% N-gain untuk kelas eksperimen dan kelas kontrol dapat dilihat pada Gambar 2. 


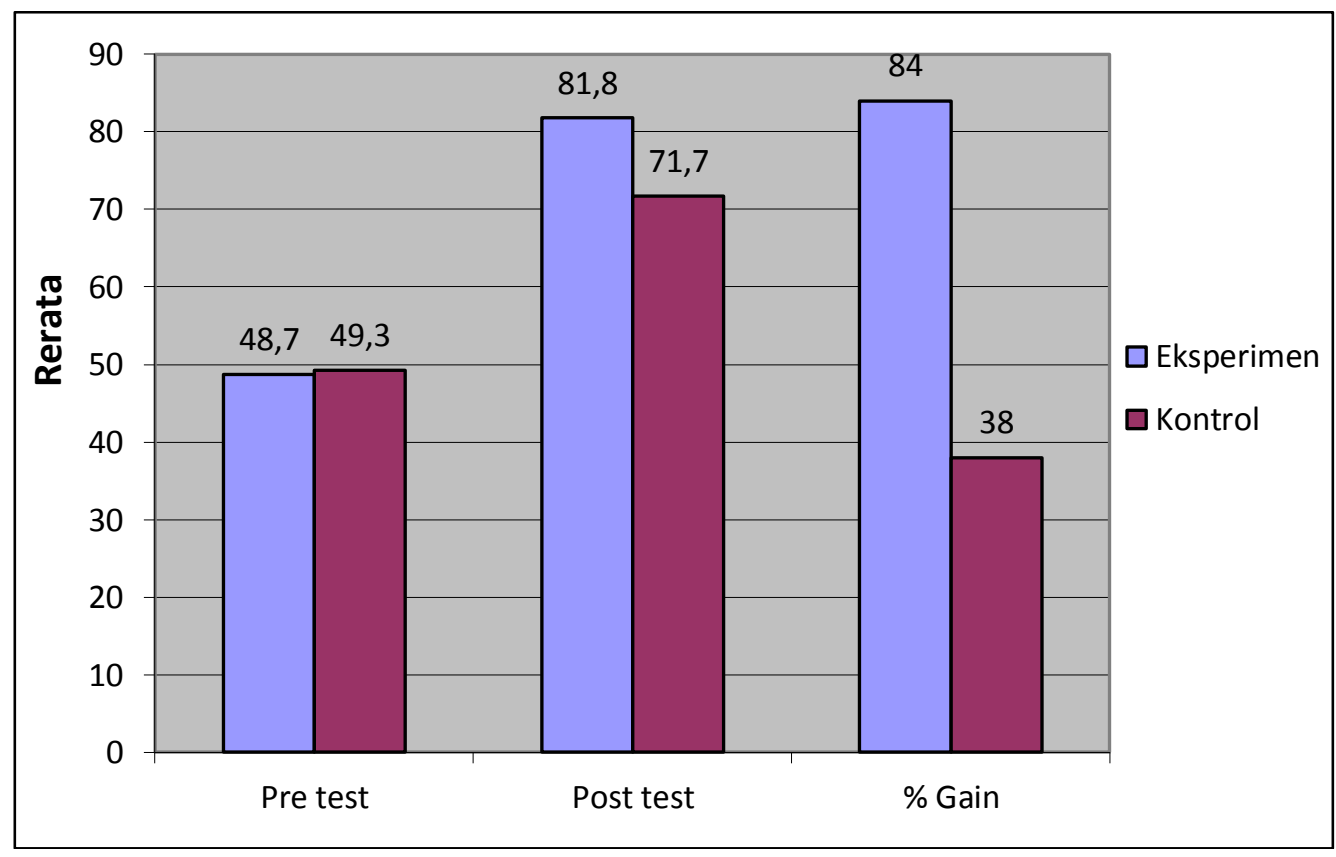

Gambar 2. Hasil Pre Test, Post Test dan \% N-gain

Sumber: Data diolah, 2014

Hasil pre test kelas eksperimen mempunyai rerata 48,7 , lebih rendah dari kelas kontrol yang mempunyai rerata 49,3. Sedangkan rerata hasil pre test pada kelas kontrol lebih rendah yakni sebesar 71,1 dan kelas eksperimen memperoleh rerata nilai 81,8. Persentase $\mathrm{N}$-gain kelas eksperimen diperoleh $84 \%$ dan kelas kontrol $38 \%$, sehingga peningkatan nilai karakter eserta didik kelompok eksperimen lebih tinggi dibandingkan dengan kontrol.
Nilai-nilai karakter yang di integrasikan sebagai tolak ukur ketercapaian penelitian adalah (1) religius, (2) sopan santun, (3) keberanian, dan (4) tanggung jawab. Adapun perolehan skor masing-masing nilai karakter pada pre test dan post test dapat dilihat pada Tabel 2 dibawah ini.

Tabel 2. Nilai Karakter pada Pre test dan Post test

\begin{tabular}{|c|c|c|c|c|c|c|c|c|c|}
\hline \multirow{2}{*}{ No } & \multirow{2}{*}{ Karakter } & \multicolumn{4}{|c|}{ Pre Test } & \multicolumn{4}{c|}{ Post Test } \\
\cline { 3 - 11 } & & \multicolumn{2}{|c|}{ Eksperimen } & \multicolumn{2}{c|}{ Kontrol } & \multicolumn{2}{c|}{ Eksperimen } & \multicolumn{2}{c|}{ Kontrol } \\
\cline { 3 - 10 } & Skor & Kriteria & Skor & Kriteria & Skor & Kriteria & Skor & Kriteria \\
\hline 1. & Religius & 2,2 & MT & 2,2 & MT & 3,2 & MB & 3,0 & MB \\
\hline 2. & $\begin{array}{c}\text { Sopan } \\
\text { santun }\end{array}$ & 1,9 & MT & 1,9 & MT & 3,2 & MB & 2,8 & MB \\
\hline 3. & Keberanian & 1,8 & MT & 1,8 & MT & 3,3 & M & 2,8 & MB \\
\hline 4. & $\begin{array}{c}\text { Tanggung } \\
\text { jawab }\end{array}$ & 1,9 & MT & 1,9 & MT & 3,4 & M & 2,8 & MB \\
\hline
\end{tabular}

Kriteria Skor : $1 \quad-1,75=$ BT

$$
\begin{aligned}
& 1,76-2,50=\mathrm{MT} \\
& 2,51-3,25=\mathrm{MB} \\
& 3,26-4,00=\mathrm{M}
\end{aligned}
$$

Dari Tabel 2 di atas dapat dilihat pada hasil skor nilai karakter pada pre test dan post test mendapat kriteria mulai terlihat pada masing-
Keterangan Kriteria : BT = Belum Terlihat $\mathrm{MT}=$ Mulai Terlihat $\mathrm{MB}=$ Mulai Berkembang $\mathrm{M}=$ Membudaya masing nilai karakternya, baik itu kelas eksperimen maupun kelas kontrol. Dan hasil post testnya pada kelas eksperimen dan kelas kontrol 
nilai karakter religius dan sopan santun, masingmasing memperoleh kriteria mulai berkembang. Nilai karakter keberanian dan tanggung jawab pada kelas eksperimen memperoleh kriteria membudaya, dibandingkan pada kelas kontrol memperoleh kriteria mulai berkembang. Sehingga nilai karakter yang paling meningkat pada penelitian ini adalah keberanian dan tanggung jawab yang sudah membudaya, dibadingkan nilai karakter religius dan sopan santun yang masih dalam kriteria mulai berkembang.

Menurut Lickona (2012) karakter dikonsepsikan memiliki tiga bidang yang saling terkait yakni Moral Knowing, Moral Feeling, dan
Moral Action. Oleh karena itu, karakter yang baik memiliki tiga kompetensi, yakni mengetahui hal yang baik (knowing to good), ada keinginan terhadap hal yang baik (desiring the good), dan melakukan hal yang baik (Doing the good) sehingga pada gilirannya ia menjadi kebiasaan berfikir, kebiasaan hati dan kebiasaan bertindak.

Untuk mengetahui ada tidaknya perbedaan karakter peserta didik saat pre test, post test dan peningkatannya pada kelas eksperimen dan kelas kontrol maka dilakukan uji t. Hasil uji $\mathrm{t}$ untuk peningkatan karakter peserta didik dapat dilihat pada Tabel 3 Berikut ini.

Tabel 3. Hasil Uji t terhadap Pre Test, Post Test dan $\%$-gain

\begin{tabular}{|c|c|c|c|}
\hline & Pre test & Post test & \% N-Gain \\
\hline P-value/Sig. & 0,464 & 0,000 & 0,000 \\
\hline Kesimpulan & $\begin{array}{c}\text { Tidak ada perbedaan } \\
\text { Signifikan }\end{array}$ & $\begin{array}{c}\text { Ada perbedaan } \\
\text { Signifikan }\end{array}$ & $\begin{array}{c}\text { Ada perbedaan } \\
\text { Signifikan }\end{array}$ \\
\hline
\end{tabular}

Sumber: Data diolah, 2014

Berdasarkan pada Tabel 3 diketahui bahwa hasil belajar kedua kelompok peserta didik pada saat pre test tidak ada perbedaan signifikan. Sedangkan pada hasil post test dan \% N-Gainnya terdapat perbedaan yang signifikan. Pembelajaran di kelas eksperimen dapat meningkatkan karakter peserta didik dibandingkan dengan kelas kontrol. Hal ini menegaskan bahwa pembelajaran menggunakan bahan ajar kurtilas dengan strategi 3M lebih efektif dalam meningkatkan karakter peserta didik.
Sedangkan uji keefektifan bahan ajar kurtilas dengan menggunakan strategi 3M diperoleh dari penguasaan konsep, yang dilakukan dengan memberikan soal pre test dan post test di kelas eksperimen dan kelas kontrol. Untuk mengetahui ada tidaknya perbedaan pengetahuan peserta didik saat pre test, post test dan peningkatannya pada kelas eksperimen dan kelas kontrol maka dilakukan uji t. Hasil uji $\mathrm{t}$ untuk peningkatan hasil belajar dapat dilihat pada Tabel 4 berikut ini.

Tabel 4. Hasil Uji t Terhadap Pre Test, Post Test dan \%N-gain

\begin{tabular}{|c|c|c|c|}
\hline & Pre test & Post test & \% N-Gain \\
\hline P-value/Sig. & 0,452 & 0,011 & 0,001 \\
\hline Kesimpulan & $\begin{array}{c}\text { Tidak ada perbedaan } \\
\text { Signifikan }\end{array}$ & $\begin{array}{c}\text { Ada perbedaan } \\
\text { Signifikan }\end{array}$ & $\begin{array}{c}\text { Ada perbedaan } \\
\text { Signifikan }\end{array}$ \\
\hline
\end{tabular}

Sumber : Data diolah, 2014

Berdasarkan pada Tabel 4 diketahui bahwa hasil belajar kedua kelompok peserta didik pada saat pre test tidak ada perbedaan signifikan. Sedangkan pada hasil post test dan \% N-Gainnya terdapat perbedaan yang signifikan. Pembelajaran di kelas eksperimen pada sub tema Pekerjaan Orang Tuaku ternyata dapat meningkatkan pengetahuan (kognitif) peserta didik dibandingkan dengan kelas kontrol. Hal ini menegaskan bahwa pembelajaran menggunakan bahan ajar kurtilas dengan strategi 3M lebih baik dan mudah di pahami oleh peserta didik.

Selanjutnya untuk mengetahui pengaruh penggunaan bahan ajar kurtilas dengan strategi 3M maka dilakukan uji regresi terhadap data pre test dan post test masing-masing kelas. Hasil 
analisis menunjukkan bahwa harga $\mathrm{F}$ tabel cocok sebesar 5,614 dengan signifikansi 0,053 (di atas $0,05)$. Berarti bahan ajar kurtilas dengan strategi 3M nilai karakter peserta didik.

\section{SIMPULAN}

Berdasarkan hasil penelitian disimpulkan beberapa hal bahwa karakteristik bahan ajar yaitu pada sub tema pekerjaan orang tuaku. Bahan ajar yang diterapkan yaitu mengintegrasikan nilai karakter yang di dalamnya terdapat moral knowing, moral feeling \& moral action. Implementasi pendidikan karakter menggunakan strategi $3 \mathrm{M}$ ini termuat dalam beberapa kegiatan yang ada pada bahan ajar.

Nilai-nilai karakter yang di integrasikan sebagai tolak ukur ketercapaian penelitian adalah (1) religius, (2) sopan santun, (3) keberanian, dan (4) tanggung jawab. Hasil rerata nilai karakter religius pada kelas eksperimen sebesar 3,2 (mulai berkembang) dan kelas kontrol 3,0 (mulai berkembang), rerata nilai karakter sopan santun pada kelas eksperimen sebesar 3,2 (mulai berkembang) dan kelas kontrol 2,8 (mulai berkembang), rerata nilai karakter keberanian pada kelas eksperimen sebesar 3,3 (membudaya) dan kelas kontrol sebesar 2,8 (mulai berkembang), nilai karakter tanggung jawab pada kelas eksperimen sebesar 3,4 (membudaya) dan kelas kontrol sebesar 2,8 (mulai berkembang). Jadi dapat disimpulkan bahwa nilai karakter keberanian dan tanggung jawab pada kelas eksperimen lebih baik di banding dengan kelas kontrol, hal ini ditandai dengan kriteria nilai karakternya yang sudah membudaya.

Berdasarkan hasil uji regresi padadata pre test dan post test di masing-masing kelas didapat nilai signifikansinya sebesar 0,053 (lebih besar dari 0,05), sehingga dapat dikatakan bahwa bahan ajar kurtilas dengan strategi $3 \mathrm{M}$ dapat meningkatkan karakter peserta didik.

\section{REFERENSI}

Amri, S, Jauhari, A, \& Elisah, T. (2012). Implementasi Pendidikan Karakter dalam Pembelajaran. Jakarta: PT. Prestasi Pustakaraya.

Beck, C.M., Critender, BS, and Sullivan, E.V. (1981). Moral Education: Interdisinary Approach. University of Toronto Press.

Benninga, J.S. (2003). The Relationship of Character Education Implementation and Academic Achievement in Elementary Schools. Journal of Research in Character Education 1(1) (1543-1223).

Hasan, H. (2010). Pengembangan Pendidikan Budaya dan Karakter. Jakarta: Kementrian Pindidikan Nasional Badan Penelitian dan Pengembangan Pusat Kurikulum.

Kementrian Pendidikan dan Kebudayaan. (2013). Materi Pelatihan Guru Implementasi Kurikulum 2013. Badan Pengembangan Sumber Daya Manusia Pendidikan dan Kebudayaan.

Lickona, T. (2012). Persoalan Karakter. Terjemahan Juma Abdu Wamungo dan Jean Antunes Rudolf Zien. Jakarta: Bumi Aksara.

Lickona, T. (2012). Pendidikan Karakter. Penerjemah Saut Pasaribu. Jakarta: Kreasi Wacana.

Megawangi, R. (2004). Pendidikan Karakter Solusi yang Tepat untuk Membangun Karakter Bangsa.

Pala, A. (2011). The Need for Education Character. International Journal of Social Sciences and Humanity Studies. 3(2) ISSN 13098063 (Online). 